\title{
Addition of Yeast Bread (Saccharomyces cerevisiae) in Feed to Increase Growth of Barramundi (Lates calcarifer)
}

\author{
Ika Linda Hartati ${ }^{1}$, Nunik Cokrowati ${ }^{{ }^{*}}$, Dewi Putri Lestari ${ }^{1}$ \\ ${ }^{1}$ Program Studi Budidaya Perairan, Jurusan Perikanan dan Ilmu Kelautan, Fakultas Pertanian, \\ Universitas Mataram, Lombok, Nusa Tenggara Barat.
}

\author{
Article History \\ Received : July $15^{\text {th }}, 2020$ \\ Revised : July $19^{\text {th }}, 2020$ \\ Accepted : August $5^{\text {th }}, 2020$ \\ Published : August 6 ${ }^{\text {th }}, 2020$ \\ *Corresponding Author: \\ Nunik Cokrowati, \\ Program Studi Budidaya \\ Perairan, Jurusan Perikanan dan \\ Ilmu Kelautan, Fakultas \\ Pertanian, Mataram, Lombok \\ Nusa Tenggara Barat. \\ Email: \\ nunikcokrowati@unram.ac.id
}

\begin{abstract}
Barramundi (Lates calcarifer) is known as Sea bass with a selling price of Rp.75,000 - Rp.80,000/Kg consumption size. The purpose of this study was to determine the effect of the addition of bread yeast with different doses to feed on the growth of Lates calcarifer. This study uses an experimental method with a Completely Randomized Design (CRD). The treatments were $\mathrm{P} 0=0 \%$ yeast, $\mathrm{P} 1=0.5 \%, \mathrm{P} 2=0.10 \%, \mathrm{P} 3=0.15 \%, \mathrm{P} 4=0.20 \%$ yeast from the weight of the feed given. The results of the study are the bread yeast influences the growth of Lates calcarifer. The highest absolute weight gain in P4 treatment was $0.507 \mathrm{~g}$. The highest absolute length increase in P4 treatment was $0.990 \mathrm{~cm}$. The lowest FCR at perlakuan P1 yaitu 15,55. The highest survival rates are P2, P3, and P4 which is $100 \%$. Erythrocytes with the highest total amount in $\mathrm{P} 4$ treatment $12,58 \times 10^{6}-18,62 \times 10^{6}$ cells $/ \mathrm{mm}^{3}$. Leukocytes with the highest total number in P2 treatment were $27,96 \times 10^{6}-44,641 \times 10^{6}$ cells $/ \mathrm{mm}^{3}$. Water quality parameter values in the maintenance media are in the range of requirements for Lates calcarifer cultivation. The conclusion of the study is the addition of bread yeast affects the growth of Lates calcarifer and the optimal dose that can increase the growth is $0,20 \%$.
\end{abstract}

Keywords: Pellet; immunostimulant; weight; length; blood cells; water quality.

\section{Pendahuluan}

Ikan kakap putih (Lates calcarifer) merupakan spesies asli Thailand yang dikenal dengan nama sea bass atau ikan Barramundi. Spesies ini kemudian menyebar secara luas ke wilayah Indo-Pasifik dari laut Arab ke laut China, Taiwan, Papua New Guinea dan laut Utara Australia (FAO, 2013). Menurut Siddik et al., (2016) bahwa spesies ini memijah di perairan laut dan tumbuh dewasa di lingkungan air tawar serta mampu hidup pada salinitas yang luas. Ikan kakap putih memiliki nilai ekonomis serta nilai jual yang tinggi. Harga ikan kakap putih di tingkat pembudidaya di Teluk Lampung berkisar Rp.75.000 - Rp.80.000/Kg (Yaqin et al., 2018). Menurut Hikmayani et al., (2012) menjelaskan bahwa ikan kakap putih memiliki pertumbuhan relatif cepat, mudah menyesuaikan diri dengan lingkungan budidaya serta memiliki toleransi yang tinggi terhadap salinitas yaitu berkisar 0-40 ppt.

Pakan yang tepat untuk ikan kakap putih adalah 5$10 \%$ dari bobot tubuh per hari (Wardoyo, 2015). Menurut SNI (1999) menjelaskan bahwa pembrian pakan yang tepat untuk benih ikan kakap putih adalah $10 \%$ dari bobot tubuh per hari. Kamarudin et all.,(2019) memberikan 4\% pakan pada ikan uji yang diberikan suplementasi ragi pada pakannya. Ragi roti mudah diperoleh di pasar dan harganya terjangkau. Ragi roti dapat dijadikan bahan immunostimulan. Penelitian aplikasi ragi roti pada pakan ikan untuk meningkatkan pertumbuhan telah dilakukan pada ikan Jelawat, lele, mas, Gurami dan baronang (Hurriyani, 2018; Manoppo, 2016; Wibowo, 2018; Kamarudin, 2019). Li et al., (2009) menjelaskan bahwa ragi roti yang ditambahkan ke dalam pakan ikan terbukti dapat meningkatkan laju pertumbuhan ikan.

Ragi roti mengandung nukleotida dalam bentuk purin dan pirimidin. Nukleotida yang terkandung dalam ragi roti dapat meningkatkan nafsu makan ikan. Hal ini membuat ikan cenderung makan dan mampu mencerna pakan dengan baik yang mengakibatkan pertumbuhan (Burres et al., 2001). Saselah dan Mandeno (2017) menyatakan peningkatan bobot tubuh ikan berkaitan dengan kemampuan ikan dalam memanfaatkan dan mencerna pakan yang diberikan. Ragi roti juga mengandung nilai nutrisi lain meliputi protein, lemak, vitamin dan mineral. Kammarudin et al., (2019) menjelaskan hasil penelitiannya bahwa ragi roti dapat 
meningkatkan kecernaan pakan dan pertumbuhan ikan baronang. Ragi roti berfungsi sebagai probiotik yang dapat meningkatkan respon imun, memberikan enzim dalam mencerna pakan dan meningkatkan kecernaan pakan. Manurung (2015) menjelaskan hasil penelitiannya bahwa penambahan ragi roti $5 \mathrm{~g} / \mathrm{kg}$ pada pakan, dapat meningkatkan pertumbuhan ikan nila. Tujuan penelitian ini adalah untuk mengetahui pengaruh ragi roti dengan dosis yang berbeda pada pakan terhadap pertumbuhan ikan kakap putih (Lates calcarifer).

\section{Bahan dan Metode}

\section{Waktu dan Tempat}

Penelitian dilaksanakan pada tanggal 23 Januari sampai dengan 22 Februari 2020 yang bertempat di Laboratorium mandiri Karangpule Kecamatan Sekarbela Mataram Lombok Nusa Tenggara Barat.

\section{Alat dan Bahan}

Alat yang digunakan dalam penelitian adalah aerator, timbangan analitik, jangka sorong, kamera, refraktometer, thermometer, kontainer bervolume 30 liter, alat tulis, $\mathrm{pH}$, serok, lemari pendingin, ember plastik, selang sipon, sikat plastik, tissu, ember kecil, haemocytometer, hand tally counter, pipet sahli, pipet mikro, pipet tetes. Bahan yang digunakan yaitu Benih kakap putih $\pm 5-6 \mathrm{~cm}$ (Lates calcarifer, ragi roti (Saccharomyces cerevisiae), air laut, aquades, pakan pelet, EDTA 10\%, larutan truck, larutan hayem.

\section{Rancangan Penelitian}

Penelitian ini adalah penelitian eksperimen dengan menggunakan metode Rancangan Acak Lengkap (RAL) dengan perlakuan sebanyak 5 dan 3 kali ulangan. Perlakuan tersebut adalah $\mathrm{P} 0=0 \%$ ragi, $\mathrm{P} 1=0,5 \%$ ragi dari berat pakan, $\mathrm{P} 2=0,10 \%$ ragi dari berat pakan, $\mathrm{P} 3=0,15 \%$ dari ragi berat pakan, $\mathrm{P} 4=0,20 \%$ ragi dari berat pakan.

\section{Prosedur Penelitian \\ Persiapan Penelitian}

a) Persiapan Wadah dan Alat

Wadah penelitian adalah container yang berukuran $(30 \times 22 \mathrm{~cm})$ sebanyak 15 unit. Volume media yang digunakan pada adalah 20 liter air laut dan dilengakapi dengan aerasi untuk mensuplai oksigen.

b) Persiapan Media Air

Air yang digunakan adalah air laut yang diperoleh di perairan wilayah Pantai Loang Baloq Kota Mataram Lombok Nusa Tenggara Barat.

c) Persiapan Benih Ikan Kakap Putih

Ikan Kakap putih (Lates calcarifer) yang digunakan merupakan hasil budidaya di Bali, dengan ukuran $5 \mathrm{~cm}-7$ $\mathrm{cm}$. Setiap unit container berisi 10 ekor ikan.

d) Aklimatisasi
Proses aklimatisasi ikan kakap putih (Lates calcarifer) dilakukan dengan cara memasukkan ikan ke dalam baskom dan baskom tersebut dibiarkan melayang di permukaan media budidaya.

\section{Pelaksanaan Penelitian}

a) Penimbangan Bobot Awal

Penimbangan bobot awal ikan dilakukan untuk mengetahui berat awal sebelum diberikan perlakuan.

b) Pengukuran Panjang

Pengukuran panjang ikan dilakukan pada awal dan akhir pemeliharaan dengan cara mengambil 10 ekor kemudian diukur menggunakan jangka sorong.

c) Pemberian Pakan Ikan Kakap Putih

Ikan diberikan pakan pelet yang telah di semprot dengan ragi roti, pakan diberikan sebanyak dua kali sehari yaitu pada pagi pukul 08:00 dan sore pukul 16.00 WITA. d) Pengukuran Kualitas Air

Pengukuran kualitas air dilakukan pada pagi hari sebelum ikan diberikan pakan. Kualitas air yang diukur yaitu $\mathrm{pH}$, salinitas, dan suhu.

e) Penimbangan Bobot Ikan

Penimbangan bobot ikan dilakukan setiap sepuluh hari dengan cara mengambil 10 ekor ikan pada setiap container.

f) Perhitungan Total Sel Darah Putih dan sel darah merah Jumlah sel darah putih dihitung dengan bantuan mikroskop dengan perbesaran 400x. Jumlah sel darah putih total dihitung sebanyak 4 kotak besar dan dikonversikan menurut jumlah total kotak besar sehingga didapatkan jumlah sel darah per ml.

\section{Parameter Penelitian \\ Pertambahan Bobot Mutlak}

Menurut (Effendi, 1979) perhitungan petambahan berat mutlak menggunakan rumus:

Keterangan:

$$
W=W t-W o
$$

$\mathrm{W}=$ Pertambahan bobot mutlak $(\mathrm{g})$

$\mathrm{Wt}=$ Biomassa rata-rata ikan uji pada akhir penelitian $(\mathrm{g})$

Wo $=$ Biomassa rata-rata ikan uji awal penelitia $(\mathrm{g})$

\section{Pertambahan panjang mutlak}

Pertambahan panjang dihitung dengan rumus Effendi (1979):

$$
L=P t-P o
$$

Keterangan:

$\mathrm{L}=$ Pertambahan panjang mutlak ikan yang dipelihara $(\mathrm{cm})$

$\mathrm{Pt}=$ Panjang rata-rata ikan pada akhir pemeliharaan $(\mathrm{cm})$

$\mathrm{Po}=$ Panjang ikan pada awal pemeliharaan $(\mathrm{cm})$

\section{Rasio Konversi Pakan (FCR)}

Konversi pakan dihitung menggunakan rumus Effendi (1979) adalah sebagai berikut:

Keterangan: 
$\begin{array}{ll}\mathrm{FCR} & =\text { Food Conversion Ratio (rasio konversi pakan) } \\ \mathrm{Wt} & =\text { Berat ikan pada akhir penelitian }(\mathrm{g}) \\ \mathrm{Wo} & =\text { Berat ikan pada awal penelitian }(\mathrm{g}) \\ \mathrm{F} & =\text { Jumlah pakan yang dikonsumsi }(\mathrm{g})\end{array}$

Kelangsungan Hidup atau Survival Rate (SR)

Nilai SR dihitung berdasarkan rumus Biswas et al., (2011) dalam Venkatachalam et al., (2018), sebagai berikut:

Keterangan:

$$
\mathrm{SR}=\frac{N t}{N 0} \times 100 \%
$$

SR = Tingkat Kelangsungan Hidup

$\mathrm{Nt}=$ Jumlah Ikan yang Hidup diakhir

N0 = Jumlah Ikan yang ditebar diawal.

\section{Perhitungan Total Sel Darah}

Mengacu pada penelitian yang dilakukan oleh Puspasari (2010) dalam Ilham (2018), perhitungan sel darah dengan rumus:

$\sum$ Sel Darah Putih $\left(\mathrm{sel} / \mathrm{mm}^{3}\right)=$ Jumlah sel terhitung $\mathrm{x}$
$\frac{1}{\text { volume kotak besar }} \times$ faktor pengenceran

Faktor Pengenceran $=\frac{W 1+W 2+W 3+W 4}{4} \times 50 \times 22$

$\sum$ Sel Darah Merah $\left(\mathrm{sel} / \mathrm{mm}^{3}\right)=$ Jumlah sel terhitung $\mathrm{x} \frac{1}{\text { volume kotak kecil }}$ $\mathrm{x}$ faktor pengenceran

Faktor Pengenceran $=\frac{R 1+R 2+\cdots+R 9+R 10}{10} \times \frac{1}{0,2 \times 0,2 \times 0,1 \mathrm{~mm} 3} \times 200$

\section{Pengukuran Kualitas Air}

Parameter kualitas air yang diamati adalah $\mathrm{pH}$, suhu, salinitas. Pengukuran dilakukan setiap hari pada pagi hari.

\section{Analisis Data}

Untuk mengetahui pengaruh ragi roti terhadap pertumbuhan digunakan analisis sidik ragam ANOVA menggunakan program SPSS untuk Windows.

\section{Hasil dan Pembahasan}

\section{Pertumbuhan Berat Mutlak}

Pertumbuhan berat mutlak sebagaimana pada grafik di bawah ini. Pertumbuhan berat mutlak tertinggi didapatkan pada perlakuan P4 sebesar 0,507 g, sedangkan pertumbuhan berat mutlak terendah pada perlakuan P0 sebesar $0,427 \mathrm{~g}$.

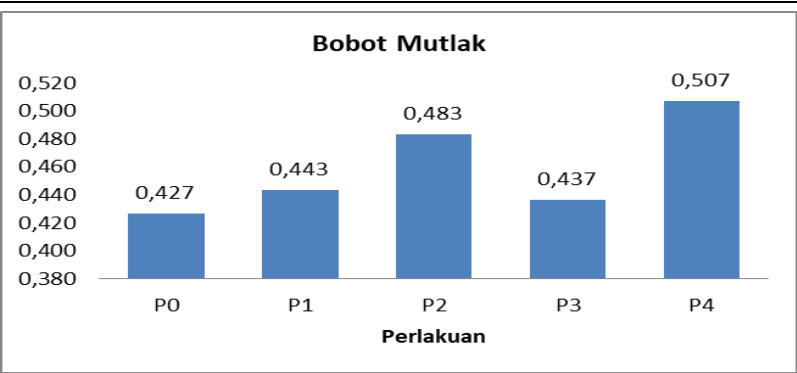

Gambar 2. Pertumbuhan Berat Mutlak Ikan Kakap Putih.

Keterangan : Perlakuan $\mathrm{P} 0=($ tanpa ragi roti. $), \mathrm{P} 1=(0,5 \%$ ragi roti $)$, $\mathrm{P} 2=(0,10 \%$ ragi roti $), \mathrm{P} 3=(0,15 \%$ ragi roti $), \mathrm{P} 4=(0,20 \%$ ragi roti $)$.

Berdasarkan analisis One-way (ANOVA) menunjukkan bahwa kelima perlakuan penambahan ragi roti pada pakan memberikan pengaruh pertumbuhan berat yang signifikan. Pertambahan berat ikan dipengaruhi oleh jumlah pakan yang dikonsumsi. Rendahnya pertumbuhan berat mutlak pada perlakuan P0 diduga karena tidak diberi penambahan ragi roti (Saccharomyces cerevisiae). Hal ini berbanding terbalik dengan perlakuan pakan yang di semprot dengan ragi roti (Saccharomyces cerevisiae). Perlakuan P4 merupakan perlakuan terbaik sehingga meningkatkan pertumbuhan mutlak kakap putih. Hal ini sesuai dengan hasil penelitian Yin et al., (2006) bahwa ikan yang diberi pakan dengan imunostimulan ragi roti (Saccharomyces cerevisiae) mengalami peningkatan sistem kekebalan tubuh dan nafsu makan.

\section{Pertumbuhan Panjang Mutlak}

Pertumbuhan panjang mutlak sebagaimana pada grafik dibawah ini. Pertambahan panjang mutlak tertinggi didapatkan pada perlakuan P4 yaitu $0,990 \mathrm{~cm}$, dan terendah pada perlakuan P0 sebesar $0,267 \mathrm{~cm}$.

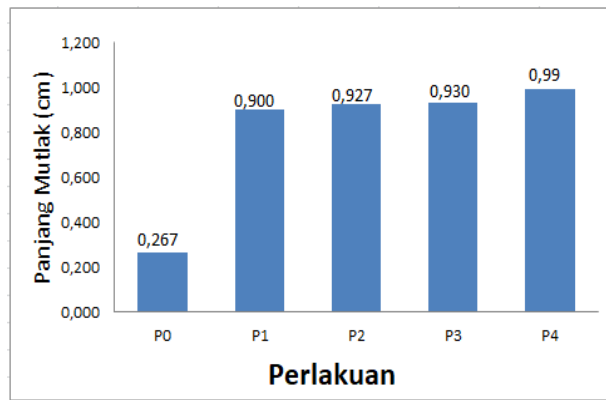

Gambar 3. Pertumbuhan Panjang Mutlak

Keterangan : Perlakuan $\mathrm{P} 0=($ tanpa ragi roti. $), \mathrm{P} 1=(0,5 \%$ ragi roti $), \mathrm{P} 2=$ $(0,10 \%$ ragi roti), $\mathrm{P} 3=(0,15 \%$ ragi roti $), \mathrm{P} 4=(0,20 \%$ ragi roti $)$.

Berdasarkan analisis One-way (ANOVA) menunjukkan bahwa kelima perlakuan penambahan ragi roti pada pakan memberikan pengaruh terhadap pertambahan panjang mutlak. Nayak (2010) menjelaskan bahwa $S$. cerevisiae telah diuji cobakan pada komoditas 
akuakultur maupun hewan ternak karena mempunyai beberapa kelebihan yaitu bersifat non-patogenik, bebas dari plasmid yang mengkodekan gen resisten terhadap antibiotik, dan mampu bertahan pada kondisi asam dan basa.

S. cerevisiae diketahui mampu memproduksi beberapa substrat energi pada sel-sel intestinal, sehingga usus menjadi lebih sehat. Kandungan nukleotida pada ragi roti juga mampu memperbaiki kerusakan intestinal dengan cepat dan meningkatkan flora pada mucosal usus ekstrak dinding sel. $S$. cerevisiae merupakan imunostimulan alami dan juga berperan sebagai promotor pertumbuhan. Li et al., (2003) menyatakan bahwa penambahan ragi roti dapat meningkatkan pertumbuhan karena ragi roti mengandung nukleotida. Ragi roti mengandung nukleotida dalam bentuk basah purin dan pirimidin sebanyak 0,9 \%. Burrels et al., (2001) menjelaskan bahwa Saccharomyces cerevisiae mengandung nukleotida yang dapat meningkatkan pertumbuhan ikan, karena mampu meningkatkan nafsu makan ikan.

\section{Rasio Konversi Pakan atau Feed Convertion Ratio (FCR)}

Hasil perhitungan FCR selama pemeliharaan 30 hari, didapatkan pada perlakuan P3 yaitu 20,63 memiliki nilai suplementasi konversi pakan tertinggi sedangkan konversi pakan terendah diperoleh pada perlakuan P1 yaitu 15,55. Berikut adalah grafik FCR setiap perlakuan.

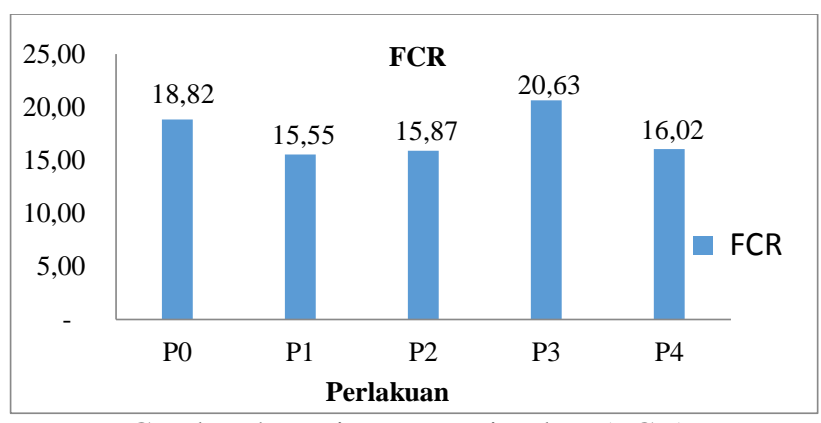

Gambar 4. Rasio Konversi Pakan (FCR)

Keterangan: Perlakuan $\mathrm{P} 0=($ tanpa ragi roti. $), \mathrm{P} 1=(0,5 \%$ ragi roti $), \mathrm{P} 2=$ $(0,10 \%$ ragi roti), $\mathrm{P} 3=(0,15 \%$ ragi roti $), \mathrm{P} 4=(0,20 \%$ ragi roti $)$.

Penambahan ragi roti pada pakan memberikan pengaruh pada Rasio Konversi Pakan yang signifikan. Konversi pakan yang baik dihasilkan pada perlakuan P1, P2 dan P4 dikarenakan kemampuan Saccharomyces cerevisiae dalam meningkatkan pencernaan enzimatik terhadap senyawa polisakarida kompleks termasuk selulosa, asam sitrat, dan serat. Saccharomyces cerevisiae juga berperan dalam meningkatkan kecernaan pakan dan mampu memperbaiki keseimbangan mikroflora intestinal. Sehingga ikan menjadi lebih baik dalam mencerna nutrien yang terkandung dalam pakan. Menurut pendapat
Whittington et al., (2005) Saccharomyces cerevisiae diketahui mampu memproduksi vitamin B kompleks terutama Biotin dan vitamin B12 yang diperlukan ikan dalam proses pencernaan yang baik. Saccharomyces cerevisiae juga mampu memproduksi subtansi seperti glutamine, glutamic acid, keto glutamic acid yang digunakan sebagai substrat energi pada sel usus. Kandungan peptida pada sel ragi ini berperan penting dalam pencernaan ezimatik, sehingga ikan mampu mencerna makanan dengan lebih efisien.

Nilai FCR yang baik didapatkan pada perlakuan P1, P2 dan P4. Menurut Garcia et al., (2012) menjelaskan bahwa nilai konversi pakan yang rendah menunjukkan pakan yang diberikan pada ikan budidaya terserap secara optimum oleh tubuh ikan dan digunakan untuk pertambahan berat tubuh. Hal yang sama juga dikemukakan oleh Iskandar et al., (2015), juga menjelaskan semakin kecil nilai rasio konversi pakan berarti tingkat efesiensi pakan lebih baik, sebaliknya semakin besar nilai konversi pakan maka tingkat efesiensi pakan kurang baik.

Tingkat Kelangsungan Hidup atau Survival Rate (SR) Kelangsungan hidup tertinggi yaitu pada perlakuan P2, P3 dan P4 sebesar 100\%. Hal ini menunjukkan bahwa ikan kakap putih tidak mengalami kematian saat pemeliharaan, sedangkan SR terendah pada perlakuan P0 yaitu $86.67 \%$. Berikut adalah grafik nilai SR setiap perlakuan.

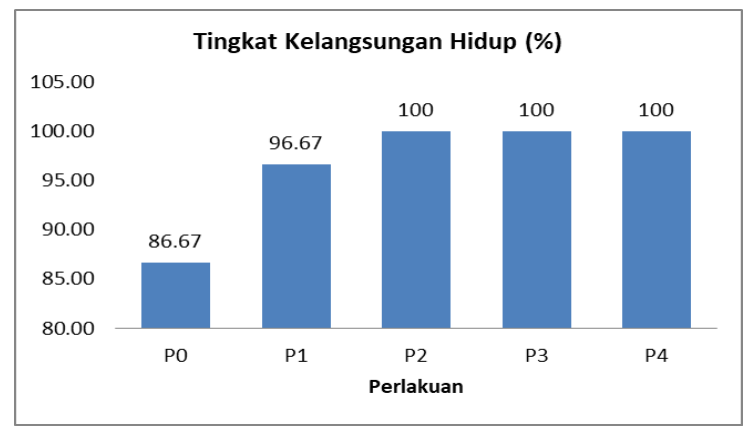

Gambar 5. Tingkat kelangsungan hidup

Keterangan: Perlakuan $\mathrm{P} 0=($ tanpa ragi roti $), \mathrm{P} 1=(0,5 \%$ ragi roti $)$, $\mathrm{P} 2=(0,10 \%$ ragi roti $), \mathrm{P} 3=(0,15 \%$ ragi roti $), \mathrm{P} 4=(0,20 \%$ ragi roti $)$.

Penambahan ragi roti memberikan pengaruh terhadap tingkat kelangsungan hidup ikan kakap putih. Pada perlakuan P4 dengan nilai SR $100 \%$, menunjukkan bahwa ikan kakap putih memiliki ketahanan tubuh yang kuat terhadap lingkungannya walaupun ikan kurang dalam merespon pakan yang diberikan. Hardianti et al., (2016) menjelaskan bahwa faktor yang mempengaruhi tinggi rendahnya kelangsungan hidup adalah faktor abiotik dan biotik, yaitu kompetitor, kepadatan populasi, umur dan kemampuan organisme dalam beradaptasi dengan lingkungan. Asma et al., (2016) menjelakan 
bahwa suhu mempengaruhi kelangsungan hidup ikan, jika perubahan suhu sering terjadi setiap hari dapat menyebabkan ikan stres, nafsu makan ikan berkurang sehingga menghambat pertumbuhan dan sebagian mengalami kematian. Tingkat kelangsungan hidup sangat erat kaitannya dengan mortalitas yakni kematian yang terjadi pada suatu populasi organisme sehingga jumlahnya berkurang. Adelina (2000) menjelaskan bahwa kelangsungan hidup merupakan persentase populasi organisme yang hidup tiap periode waktu pemeliharaan tertentu.

\section{Sel Darah Merah}

Eritrosit dengan jumlah total tertinggi pada perlakuan P4 yaitu $12,58 \times 10^{6}-18,67 \times 10^{6} \mathrm{sel} / \mathrm{mm}^{3}$, kemudian diikuti P3 sebanyak $11,85 \times 10^{6}-18,52 \times 10^{6}$ $\mathrm{sel} / \mathrm{mm}^{3}$, P2 sebanyak $12,93 \times 10^{6}-18,33 \times 10^{6} \mathrm{sel} / \mathrm{mm}^{3}$, dan $\mathrm{P} 1$ sebanyak $12,33 \times 10^{6}-18,28 \times 10^{6} \mathrm{sel} / \mathrm{mm}^{3}$. Berikut adalah grafik jumlah sel darah merah setiap perlakuan.

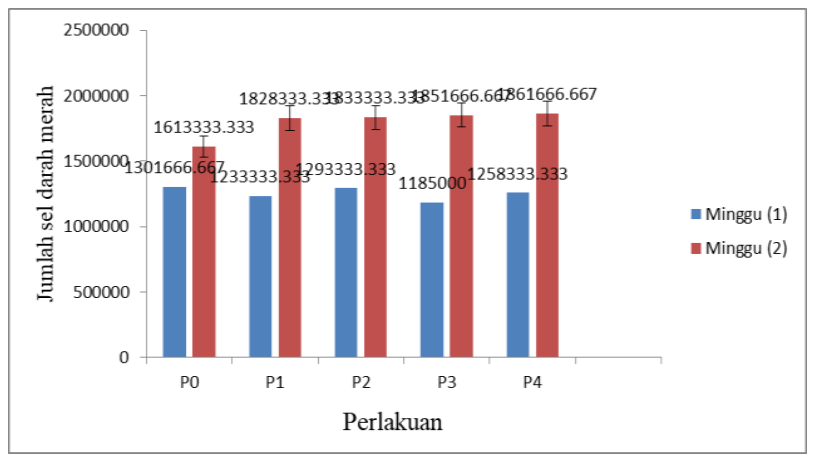

Gambar 6. Grafik total sel darah merah

Keterangan: Perlakuan $\mathrm{P} 0=($ tanpa ragi roti.), $\mathrm{P} 1=(0,5 \%$ ragi roti $)$, $\mathrm{P} 2=(0,10 \%$ ragi roti $), \mathrm{P} 3=(0,15 \%$ ragi roti $), \mathrm{P} 4=(0,20 \%$ ragi roti $)$.

Penambahan ragi roti pada pakan memberikan pengaruh yang signifikan pada jumlah sel darah merah. Terlihat bahwa terjadi peningkatan jumlah sel darah merah seiring dengan penambahan jumlah $S$. cerevisiae dalam pakan. Peningkatan sel eritrosit ini seiring dengan peningkatan aktivitas fogositosis. Raa (2000) menjelaskan bahwa diantara bahan yang berpotensi sebagai imunostimulan adalah ragi roti ( $S$. cerevisiae) maupun produk sampingan dari industri ragi roti (yeastby product). Hal yang sama juga dikemukakan oleh (Yin et al., 2006) menjelaskan bahwa mekanisme kerja imunostimulan dalam merangsang sistem imun adalah dengan cara meningkatkan Aktivitas sel-sel fagosit. Hal yang sama dikemukakan oleh (Li et al., 2003) bahwa ragi roti dapat meningkatkan aktifitas fagositosis karena bahan ini selain mengandung asam nulkleat dan nukleotida, juga mengandung $\beta$-glucan. $\beta$-glucan dapat meningkatkan aktifitas fagositosis dengan cara berikatan terlebih dahulu dengan molekul reseptor yang terdapat pada permukaan sel-sel fagosit. Setelah berikatan maka sel fagosit akan diaktifkan. Hal yang sama juga dikemukakan oleh (Sakai et al., 2001) juga mendapatkan pemberian ekstrak ragi roti 15 mg/ikan memperlihatkan peningkatan aktifitas fagositosis. Penelitian yang dilakukan oleh Rayes et al., (2008), pemberian $\beta$-glucan secara nyata meningkatkan aktifitas fagositosis pada ikan rohu (L.rohita). Manurung (2013) mendapatkan hasil yang sama dimana ikan nila yang dibepelihara di akuarium dan diberi ragi roti 10 - 20 $\mathrm{g} / \mathrm{kg}$ pakan memiliki aktifitas fagositosis yang lebih tinggi dibandingkan dengan ikan kontrol.

\section{Sel Darah Putih}

Hasil pengamatan jumlah sel darah putih atau leukosit menunjukkan bahwa jumlah total tertinggi pada perlakuan P2 yaitu $27,96 \times 10^{6}-44,64 \times 10^{6} \mathrm{sel} / \mathrm{mm}^{3}$,

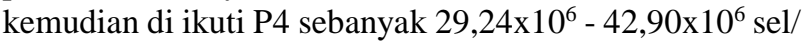
$\mathrm{mm}^{3}$, P3 sebanyak $29,88 \times 10^{6}-42,72 \times 10^{6} \mathrm{sel} / \mathrm{mm}^{3}, \mathrm{P} 1$ sebanyak $28,60 \times 10^{6}-37,68 \times 10^{6} \mathrm{sel} / \mathrm{mm}^{3}$ dan P0 28,69 $\mathrm{x} 10^{6}-29,43 \times 10^{6} \mathrm{sel} / \mathrm{mm}^{3}$.

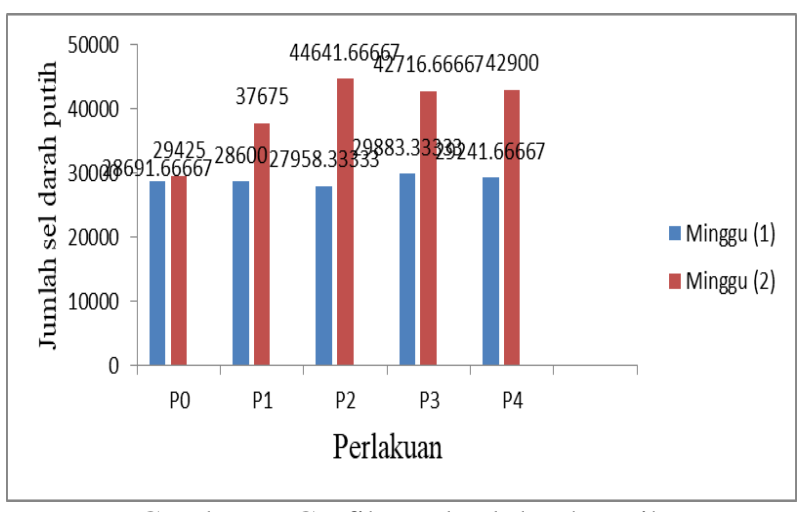

Gambar 7. Grafik total sel darah putih

Keterangan: Perlakuan $\mathrm{P} 0=($ tanpa ragi roti. $), \mathrm{P} 1=(0,5 \%$ ragi roti $)$, $\mathrm{P} 2=(0,10 \%$ ragi roti $), \mathrm{P} 3=(0,15 \%$ ragi roti $), \mathrm{P} 4=(0,20 \%$ ragi roti $)$.

Penambahan ragi roti pada pakan memberikan pengaruh pada jumlah sel darah putih. Pada penelitian ini terjadi peningkatan jumlah sel darah putih seiring dengan penambahan $S$. cerevisiae dalam pakan. Peningkatan sel leukosit lebih banyak infiltrasi sel radang meluas pada epidermis. (Li et al., 2003) menyatakan bahwa ragi roti mengandung bahan-bahan yang berfungsi sebagai immunomodulator seperti nukleotida. Nukleotida adalah nutrient semi esensial dan bahan ini dibutuhkan untuk pertumbuhan dan perbanyakan sel organisme hidup serta mengoptimalkan fungsi-fungsi pembelahan sel termasuk sel-sel imun. Hal yang sama di kemukakan oleh Sajeevan et al., (2006) bahwa nukeotida akan diurai oleh enzim nukleotridase untuk melepas molekul fosfat dan menghasilkan nukleosida. Nukleosida kemudian diurai oleh enzim nukleosidase untuk melepas molekul gula dan menghasilkan basa purin dan pirimidin. Purin dan pirimidin akan digunakan untuk membentuk nukleotida yang dibutuhkan untuk pembentukan DNA dan 
perbanyakan atau pembentukan sel baru. Menurut Barnes (2006) bahwa nukleotida merupakan nutrien semiesensial yang dibutuhkan untuk pertumbuhan dan perbanyakan sel. Susandi (2017) menjelaskan bahwa peningkatan jumlah leukosit total terjadi akibat adanya respon dari tubuh ikan terhadap kondisi lingkungan, faktor stress, dan infeksi penyakit. Sakai (1999) menjelaskan bahwa dosis dan lama waktu pemberian merupakan faktor penting yang harus dipertimbangkan dalam pemberian suatu imunostimulan. Apabila imunostimulan diberikan dalam dosis yang tinggi atau berlebihan maka respon yang ditimbulkan akan dapat teramati dalam waktu yang singkat namun apabila diberikan dalam waktu yang berkepanjangan, dosis yang tinggi mungkin tidak akan meningkatkan tetapi sebaliknya mungkin menekan respon imun ikan karena bahan tersebut tidak lagi bekerja sebagai imunostimulator tetapi justru akan bekerja sebagai immunosuppresor.

\section{Kualitas Air}

Hasil pengukuran nilai parameter kualitas air selama penelitian adalah sebagaimana pada tabel berikut ini.

Tabel 1. Kisaran Nilai Parameter Kualitas Air

\begin{tabular}{|c|c|c|c|c|c|}
\hline \multirow{2}{*}{ Parameter } & \multicolumn{4}{|c|}{ Perlakuan } & \multirow{2}{*}{ Acuan } \\
\hline & A & B & $\mathrm{C}$ & $\mathrm{D}$ & \\
\hline Suhu $\left({ }^{\circ} \mathrm{C}\right)$ & $27,2-29$ & $27-28,6$ & $27-28,3$ & $27-28,9$ & $\begin{array}{l}\text { 27-32 (Jaya } \\
\text { et al., 2013) }\end{array}$ \\
\hline DO (ppm) & $5-5,5$ & $5,2-5,5$ & $5-5,3$ & $5,2-5,5$ & $\begin{array}{l}\text { 5-8 (Jaya et } \\
\text { al., 2013) }\end{array}$ \\
\hline $\mathrm{pH}$ & $7,60-7,78$ & $7,57-8,01$ & $7,58-7,93$ & $7,60-7,79$ & $\begin{array}{l}7,5-8,5 \\
\text { (Jaya et al., } \\
2013 \text { ) }\end{array}$ \\
\hline $\begin{array}{l}\text { Salinitas } \\
\text { (ppt) }\end{array}$ & $29-34$ & $29-34$ & $29-34$ & $29-34$ & $\begin{array}{l}28-35 \\
(\mathrm{SNI}, 1999)\end{array}$ \\
\hline
\end{tabular}

Perlakuan pemberian ragi roti pada pakan ikan kakap putih tidak mempengaruhi parameter kualitas air. Hal ini karena sistem pengelolaan air pada pemeliharaan menggunakan sistem ganti air sebanyak $70 \%$ setiap dua hari sehingga kondisi air selalu terbarukan. Nilai rata-rata suhu berkisar antara $27-28^{\circ} \mathrm{C}$. Kisaran suhu tersebut merupakan nilai suhu optimum untuk pendederan benih ikan kakap putih menurut SNI (1999) yaitu $28-32^{\circ} \mathrm{C}$. Pada suhu tersebut ikan kakap putih dapat melakukan proses pencernaan makanan dengan baik, sehingga diikuti pertumbuhan dan kelangsungan hidup yang baik. Suhu air juga mempengaruhi kelarutan oksigen, proses kimia dan biologi perairan. Hasil pengukuran $\mathrm{pH}$ pada semua perlakuan menunjukkan kisaran 7,3-7,75. Nilai tersbut berada pada kisaran normal untuk ikan yang hidup di perairan laut. $\mathrm{pH}$ pada air laut cenderung lebih tinggi dari pada air tawar. SNI (1999) untuk pH air media pendederan kakap putih adalah 7,5-8,5.

Hasil pengukuran salinitas berada pada kisaran 2829 ppt. Salinitas tersebut berada pada kisaran normal untuk ikan yang hidup di perairan laut. Menurut SNI (1999) salinitas yang digunakan dalam kegiatan pendederan kakap putih adalah 28-33 g/l. Kondisi salinitas yang tidak sesuai dapat mempengaruhi kehidupan ikan, baik terhadap proses fisiologis, tingkah lakunya, dan survival rate. Hasil mengukuran oksigen terlarut berkisar antara 5-5,5 ppm. Standar minimal oksigen terlarut untuk media pemeliharann benih kakap putih berdasarkan SNI (1999) adalah minimal $4 \mathrm{mg} / \mathrm{l}$. Ketersediaan oksigen terarut pada media pemeliharaan kakap putih di penelitian ini, melebihi batas minimal dan hal tersebut sangat mendukung parameter kualitas air lainnya untuk berada pada kisaran normal.

\section{Kesimpulan}

Ragi roti roti (Saccharomyces cerevisiae) berpengaruh terhadap pertumbuhan ikan kakap putih (Lates Calcarifer). Dosis ragi roti pada perlakuan P4 $0,20 \%$ adalah dosis yang terbaik dalam meningkatkan pertumbuhan ikan kakap putih.

\section{Ucapan Terima Kasih}

Penelitian ini didanai dari sumber pendanaan mandiri oleh tim peneliti. Tim peneliti menyampaikan terima kasih kepada semua pihak yang telah mendukung terlaksanakannya kegiatan ini.

\section{Referensi}

Adelina \& Idasari, B. (2000). Pengaruh Pakan Dengan Protein yang Berbeda Terhdap Pertumbuhan dan Ekresi Ammoniak Benih Ikan Beung (Mystus nemurus). Pustaka Kementerian Pertanian. http://kikp.pertanian.go.id/pustaka/opac/detailopac?id=15169.

Asma, N., Z.A., Muchlisin \& I. Hasri. (2016). Pertumbuhan dan kelangsungan hidup benih ikan peres (Osteochilus vittatus) pada ransum harian yang berbeda. Jurnal Ilmiah Mahasiswa Kelautan dan Perikanan Unsyiah, 1(1):1. https://d1wqtxts1xzle7.cloudfront.net/55861534/1 -3-1-PB.pdf?1519214260=\&response-contentdisposition=inline \%3B+filename\%3DPERTUMB UHAN_DAN_KELANGSUNGAN_HIDUP_BE NIH.pdf.

Burrels C, Williams PD \& Fomo PF. (2001). Dietary nucleotide; A novel supplement in fish feed effects on resistance to disease in salmonids. 
Aquaculture.199:159-169.

https://europepmc.org/article/agr/ind23230047.

Barnes, A. (2006). Dizetary nucleotides: Essential nutrients for shrimp growth and immunity. Center for Marine Studies, University of Queensland. https://www.researchgate.net/publication/277760 195_Enhancement_of_nonspecific_immune_response_resistance_and_growt h of Litopenaeus vannamei by oral administra ti.

Effendi, M.I. (1979). Metode Biologi Perikanan. Bogor. http://opac.lib.ugm.ac.id/index.php?mod=book d etail\&sub=BookDetail\&act=view\&typ=htmlext\& buku id=638808\&obyek id=1.

FAO (2013). On-farm feeding and feed management in aquaculture. Fisheries And Aquaculture Technical Paper. ISSN.2070-7010. ISBN 978-92-5-107978-2 (print).

E-ISBN.978-92-5-107979-9.(PDF). http://www.fao.org/fishery/affris/publications/fr/.

Garcia, M.M, Romero, J.R., Bacerril, M.R., Gonzalez, C.A.A., Cerecedol, R.C. \& Spanopoulus, M. (2012). Effect of varying dietary protein levels on growth, feeding efficiency, and proxime composition of yellow snapper Lutjanus argentiventris. Aquat Res. 40 (40):1017-1025. https://doi.org/10.1111/j.10958649.2010.02806.x https://onlinelibrary.wiley.com/doi/abs/10.1111/j. 1095-8649.2010.02806.x

Hikmayani, Y., Rismutia, H.D. \& Zahri, N. (2013). Evaluasi Kebijakan Peningkatan Produksi Perikanan Budidaya. Jakarta. Jurnal Evaluasi dan Strategi Peningkatan Kebersihan Program 3 (1); 47-65.

http://dx.doi.org/10.15578/jksekp.v3i1.232

Hardianti, Q., Rusliadi \& Mulyadi. (2016). Effect of Feeding Made with Different Composition on Growth and Survival Seeds of Barramundi (Lates calcarifer, Bloch). Jurnal Online Mahasiswa. $3(2): 1-10$

https://jom.unri.ac.id/index.php/JOMFAPERIKA/ $\underline{\text { article/view/10799. }}$.

Hurriyani, Yeni. (2018). Evaluasi Penambahan Ragi Roti Saccharomyces cerevisiae Dalam Pakan Terhadap Kinerja Pertumbuhan Benih Ikan Jelawat (Leptobarbus Hoevenii). Prosiding Seminar Nasional Penelrapan Ilmu Pengetahuan dan Teknologi. Universitas Tanjungpura Pontianak. https://www.researchgate.net/publication/325013 $\underline{236}$.

Iskandar R \& Elrifadah (2015). Pertumbuhan dan Efisiensi Pakan Ikan Nila (Oreochromis niloticus) Yang Diberi Pakan Buatan Berbasis Kiambang. Jurnal Zira'ah 40(1):18-24. ISSN Elektronik 2355-3545.

https://www.neliti.com/id/publications/224046/pe rtumbuhan-dan-efisiensi-pakan-ikan-nila oreochromis-niloticus-yang-diberi-paka.

Ilham, M. (2018). Profil Darah Ikan Mas (Cyprinus Carpio) Yang Diinfeksi Pseudomonas Fluorescens Melalui Pemberian Ekstrak Sargassum Sp. Skripsi. Program Studi Budidaya Perairan. Universitas Mataram. Dipresentasikan seminar international ICWBB 2018 di Mataram.

Jaya, B., F. Agustriani \& Isnaini. (2013). Laju Pertumbuhan dan Tingkat Kelangsungan Hidup Benih Kakap Putih (Lates calcarifer, Bloch) dengan Pemberian Pakanyang Berbeda. Maspari $\begin{array}{llll}\text { Journal, } & 5 & (1): & 58 .\end{array}$ https://www.neliti.com/publications/148747/lajupertumbuhan-dan-tingkat-kelangsungan-hidupbenih-kakap-putih-lates-calcarif.

Kamaruddin, Lideman, Usman \& Bunga, R.T. (2019). Suplementasi Ragi Roti (Saccharomyces cerevisiae) Dalam Pakan Pembesaran Ikan Baronang (Siganus guttatus). Media Akuakultur. 14 (2): 97-104. p-ISSN 1907-6762; e-ISSN 25029460

http://ejournal-balitbang.kkp.go.id/index.php/ma

Li P, Gatlin, D.M. (2003). Evaluation of brewer's yeast (Saccharomyces cerevisiae) as feed Supplement for hybrid Striped bass (Morone Chrysops x M. Saxatilis).Aquac.219:681-692.

DOI: $10.1016 / \mathrm{S} 0044-8486(02) 00653-1$ https://www.researchgate.net/publication/2228291 59 Evaluation of brewers yeast_Saccharomyces cerevisiae as_a feed_supplement_for_hybrid_st riped bass Morone chrysopsM saxatilis.

Li P, Gatlin, D.M. (2009). Nucleotide nutrition in fish; Current knowledge and future application Aquaculture.251:141-152.

http://dx.doi.org/10.31602/zmip.v40il.93

https://agris.fao.org/agrissearch/search.do?recordI $\mathrm{D}=\mathrm{US} 201301102887$.

Manurung, U.S. (2013). Evaluasi Ragi Roti (Saccharomyces cerevisiae) sebagai imunostimulan dalam meningkatkan respon imun 
non spesifik dan pertumbuhan ikan nila (Oreochromis niloticus) Fakultas Perikanan Dan Ilmu Kelautan UNSRAT (Skripsi). Manado. https://doi.org/10.35800/bdp.4.3.2016.14945. https://ejournal.unsrat.ac.id/index.php/bdp/article/ view/14945.

Manurung, U.N. (2015). Pemberian Ragi Roti (Saccharomyces cereviciae) pada Ikan Nila (Oreochromis niloticus) untuk Meningkatkan Pertumbuhan. Jurnal Ilmiah Tindalung. Vol.1 No.2. p-ISSN: 2442-7381. e-ISSN: 2655-4291. DOI: https://doi.org/10.5281/jit.v1i2.64 http://e-journal.polnustar.ac.id/jit/article/view/64

Manoppo, H. \& Magdalena, E.F.K. (2016). Penggunaan ragi roti (Saccharomyces cerevisiae) sebagai imunostimulan untuk meningkatkan resistensi ikan mas (Cyprinus carpio L) terhadap infeksi bakteri Aeromonas hydrophila. Budidaya Perairan. Vol.4. No.3:37- 47. Universitas Sam Ratulangi.Manado. DOI: https://doi.org/10.35800/bdp.4.3.2016.14945 https://ejournal.unsrat.ac.id/index.php/bdp/article/ view/14945

Nayak, S.K. (2010). Probiotics and immunity: a fish perspective fish shellfish/immunology. 30:1-13. DOI: $\quad$ 10.1016/j.fsi.2010.02.017. https://www.researchgate.net/publication/418944 08_Probiotics_and immunity_A fish_perspectiv $\underline{\mathrm{e}}$

Raa, J. (2000). The use immunostimulant in fish and shellfish feeds. University of Tromso Norway. http://nutricionacuicola.uanl.mx/index.php/acu/art icle/view/264.

Reyes-Becerril M, Tovar-Ramirez D, Ascensio-Valle F, CiveraCerecedo R, Gracia-Lopez V \& BarbosaSolomieu V. (2008). Effects of dietary live yeast Debaryomyces on the immune and antioxidant system in juvenile leopard grouper Mycteroperca rosacea exposed to stress. Aquaculture 280: 39-44. https://doi.org/10.1016/j.aquaculture.2008.03.056 https://www.sciencedirect.com/science/article/abs /pii/S0044848608002548.

SNI (Standar Nasional Indonesia). (1999). Produksi Benih Ikan Kakap Putih (Lates calcalifer, Bloch) Kelas Benih Sebar. Badan Standarisasi Nasional. https://docplayer.info/36263861-Sni-standarnasional-indonesia-benih-ikan-kakap-putih-latescalcarifer-bloch-kelas-benih-sebar.html.

Sakai, M., Taniguchi, K., Mamoto, K., Ogawa, H., and Tabata, M. (2001). Immunostimulant effects of nucleotide isolated from yeast RNA on crap, Cyprissnus carpio L.J. Fish Dis 24:433-438. https://doi.org/10.1046/j.1365-761.2001.00314.x. https://onlinelibrary.wiley.com/doi/abs/10.1046/j. 1365-2761.2001.00314.x.

Sajeevan TP, Philip R \& Singh ISB. (2009). Dose/frequency: a critical factor in the administration of glucan as immunostimulant to Indian white shrimp Fennerppenaeus indicus. Aquaculture 287: 248-252. DOI 10.1016/j.aquaculture.2008.10.045. https://www.cabdirect.org/cabdirect/abstract/2009 3279160.

Sari, W. P. \& Agustono, C.D. (2009). Pemberian Pakan Dengan Energi Yang Berbeda Terhadap Pertumbuhan Benih Ikan Kerapu Tikus (Cromileptes altivelis). Jurnal Penelitian Budidaya Perikanan. Universitas Hang tuah. Surabaya. http://dx.doi.org/10.20473/jipk.v1i2.11681. https://ejournal.unair.ac.id/JIPK/article/view/1168 $\underline{1}$

Sidik, M.A.B., Islam, M.A., Hanif, M.A, Chaklader, M.R. \& Kleindienst, R. (2016). Barramundi, Lates calcarifer (Bloch 1790) a New Dimension Farming in Coastal Bangladesh. Journal of Aquaculture. $7(12)$. https://www.longdom.org/openaccess/barramundi -lates-calcarifer-bloch-1790-a-new-dimension-tothe-fishfarming-in-coastal-bangladesh-21559546-1000461.pd.

Susandi F., Mulyana \& Rosmawati. (2017). Peningkatan Imunitas Benih Ikan Gurame (Osphronemus gourami Lac.) Terhadap Aeromonas hydrophila Menggunakan Rosella (Hibiscus sabdariffa L.). Jurnal Mina Sains ISSN: 2407-9030 Vol 3 (2). DOI: $\quad$ http://dx.doi.org/10.30997/jms.v3i2.889. https://www.unida.ac.id/ojs/jmss/article/view/889

Saselah, J. \& Mandeno, J. (2017). Aplikasi probiotik dengan bahan lokal untuk meningkatkan pertumbuhan dan tingkat kelangsungan bawal air tawar (Colossoma macropomum), e-budidaya perairan,5(3):50-56.

DOI: https://doi.org/10.35800/bdp.5.3.2017.1794 $\underline{6}$

https://ejournal.unsrat.ac.id/index.php/bdp/article/ view/17946

Tacon, A. E. J. (1987). The nutrition and Feeding Formed Fish and Shrimp. A training Manual Food and Agriculture of United Nation Brazilling, Brazil. 
108hlm.

http://www.fao.org/3/ab468e/AB468E00.htm

Venkatachalam, S., Kandasamy, K., Krishnamoorthy, I., \& Narayanasamy, R. (2018). Survival and growth of fish (Lates calcarifer) under integrated mangrove aquaculture and open-aquaculture system. Aquaculture Repost. 9:18-24. https://doi.org/10.1016/j.aqrep.2017.11.004

Whittington, R., Lim, C. \& Kleus, P.H. (2005). Effect of dietary $\beta$-glucan levels on the growth response and efficancy of Streptococcus iniae vaccine in tilapia, Oreochromis niloticus. Aquaculture. 248:217-225. DOI 10.1016/j.aquaculture.2005.04.013. https://www.infona.pl/resource/bwmeta1.element. elsevier-1f10e158-e203-3a3d-88c5$93873 \mathrm{~d} 945464$.

Wardoyo, B. (2015). Budidaya Ikan Kakap Putih (Lates calcarifer, bloch 1790) Di Keramba Jaring Apung dan Tambak. Jakarta Selatan. Skripsi. Program Studi Budidaya Perairan. Universitas Lampung. http://digilib.unila.ac.id/60893/

Wibowo, W.P., Istiyanto, S. \& Diana, R.,. (2018). Analisis Laju Pertumbuhan Relatif, Efisiensi
Pemanfaatan Pakan dan Kelulushidupan Benih Ikan Gurami (Osphronemus gouramy) Melalui Subtitusi Silase Tepung Bulu Ayam Dalam Pakan Buatan. : Indonesian Journal of Tropical Aquaculture, vol. 2, no. 1, Apr. 2018. https://doi.org/10.14710/sat.v2i1.2465. https://ejournal2.undip.ac.id/index.php/sat/article/ view/2465

Yin, G., Jeney, G., Racz, Y., Pao, X. \& Jeney, Z. (2006). Effect of two chinese (Astragalus radix and scutellaria radix) on nonspecific immunes system of tilapia, Oreochromis niloticus.Aquaculture: 235-39-47.

https://doi.org/10.1016/j.aquaculture.2005.06.038. https://www.sciencedirect.com/science/article/abs /pii/S0044848605004229.

Yaqin, M.A., Santoso, L. \& Saputra, S. (2018). Pengaruh Pemberian Pakan dengan Kadar Protein Berbeda terhadap Performa Pertumbuhan Ikan Kakap Putih (Lates calcarifer) di Keramba Jaring Apung. Skripsi. Peogram Studi Budidaya Perairan. Fakultas Pertanian. Universitas Lampung. http://digilib.unila.ac.id/31562/. 